\title{
Liliana Kalita
}

Uniwersytet Gdański

iD

ORCID https://orcid.org/0000-0002-6025-2643

\section{ZAGADKOWA SZCZELINA ROSYJSKA}

[Recenzja książki Anny Skotnickiej Szczelina. Bohater wspótczesnej prozy rosyjskiej i jego światy, Wydawnictwo Uniwersytetu Jagiellońskiego, Kraków 2020]

W odniesieniu do postaw i zachowań Rosjan stosuje się często określenie „zagadkowa dusza rosyjska”. Pojęcie to od lat fascynuje badaczy, próbujących określić jej fenomen. Swoje podejście do tego zagadnienia proponuje również Anna Skotnicka w monografii Szczelina. Bohater współczesnej prozy rosyjskiej i jego światy. Krakowska literaturoznawczyni, pracownik Instytutu Filologii Wschodniosłowiańskiej Uniwersytetu Jagiellońskiego, podjęła się w omawianej pracy „prezentacji podstawowych problemów współczesnej prozy rosyjskiej, rozpatrywanych w perspektywie postaci literackiej oraz jej postrzegania świata” (s. 271), czyniąc to za pomocą metafory szczeliny - rozdarcia, sporu, braku, mającego posmak czy to melancholijnej utraty, czy też pełnego nadziei wyzwania do pokonania wewnętrznych sprzeczności, do konfrontacji ze sobą i światem.

Swoją publikacją Anna Skotnicka wpisuje się w prowadzone w jej macierzystym ośrodku badania nad współczesną prozą rosyjską, które zaowocowały uznanym nie tylko przez polskie środowisko 
rusycystów cyklem spotkań naukowych poświęconych twórczości wybranych pisarzy rosyjskich, odbywających się pod hasłem „Знаковые имена современной русской литературы" (w ramach konferencji omawiano teksty Michaiła Szyszkina i Jewgienija Wodołazkina), w których na prawach gościa specjalnego uczestniczy sam autor.

Wybrana przez badaczkę do opisu egzystencji ponowoczesnego bohatera prozy metafora szczeliny jest bardzo aktualna. Od czasów transformacji (lata 1985-1991) mamy bowiem do czynienia w literaturze rosyjskiej już nie z harmonijnym (szczególnie modelowanym według hierarchicznego socrealistycznego kanonu) wzorcem osobowościowym człowieka, odzwierciedlającym istnienie ludzkie $\mathrm{w}$ pełnym jego wymiarze, ale $\mathrm{z}$ bytem niepewnym, pozbawionym wyraźnej formy, doświadczającym „zachwiania się, rozpadu i zmiany całościowego obrazu świata - społecznego, psychicznego i mentalnego" (s. 9). Interpretacji w kluczu antropologicznym zostały poddane teksty z przełomu XX i XXI wieku, m.in. takich pisarzy, jak Swietłana Aleksijewicz, Ludmiła Pietruszewska, Ludmiła Ulicka, Michaił Kurajew, Władimir Makanin, Roman Sienczin, Michaił Szyszkin. Wymienieni twórcy reprezentują różne nurty tematyczno-stylistyczne, podkreślając tym samym bogactwo propozycji estetycznych współczesnej Rosji literackiej i jednocześnie gwarantując odmienność potraktowania omawianego zagadnienia w jego konkretnej manifestacji. Metodologiczną podstawą rozważań, dotyczących egzystencji i codzienności bohatera współczesnej prozy rosyjskiej, są dla badaczki prace m.in. Charlesa Taylora i Agaty Bielik-Robson.

Monografia podzielona jest na trzy rozdziały, ukierunkowane od „ja” do świata. Rozdział pierwszy, zatytułowany „Ja” opancerzone, poświęcono twórczości Aleksijewicz, Kurajewa i Sienczina. W rozdziale tym przedmiotem namysłu jest podmiot wycofany, odgrodzony, zamknięty, odizolowany od wszystkiego, czego nie pojmuje umysłem. Taka postawa łączy bohaterów prozy Aleksijewicz i Kurajewa, pisarze bowiem przyglądają się człowiekowi „w momencie historycznych zwrotów” (s. 18). Rozpatrywane utwory (Czasy secondhand. Koniec czerwonego człowieka Aleksijewicz oraz Nocna 
warta Kurajewa) łączy też „forma narracji osobistej, oddanie głosu postaciom" (s. 20). Trauma, której doświadczyli bohaterowie w czasach transformacji, utrudnia im adaptację do nowych czasów, wywołując lęki, cierpienie i utrwalając poczucie niepewności jutra.

Dla utworu Aleksijewicz ważna jest kategoria pamięci, której wymiar ma charakter dramatyczny - okazuje się bowiem, iż nie sposób opowiedzieć o swoim doświadczeniu, jako, że przeszłość została utracona. W tej sytuacji istotny wydaje się więc jedynie ślad pamięci, eksponujący to, co pozostaje, i wskazujący na to, co zanikło. Badaczka wykorzystuje w swych rozważaniach tradycyjne ustalenia melanchologii i trop ten jest jak najbardziej uzasadniony.

W monologu Połubołotowa Kurajew, jak dowodzi autorka monografii, akcentuje utożsamianie się bohatera z systemem totalitarnym, którego mężczyzna był częścią. Brak dystansu, niemożność mentalnego uchwycenia rzeczywistości w jej sprzecznościach i dostrzeżenia jej absurdu sprawiają, że bohater identyfikuje się z normami przeczącymi ogólnohumanistycznym wartościom. Dopiero pozbawienie Połubołotowa przywilejów wyzwala w nim uczucie rozczarowania, jednak bez refleksji nad moralną odpowiedzialnością za swoje czyny - taka konfrontacja jest zresztą typowa dla postawy konformisty, będącego „śrubką w maszynie” totalitarnego państwa.

Zarówno Aleksijewicz, jak i Kurajew pokazują bohaterów, dla których ślady pamięci to „znak katastrofy i zniszczenia” (s. 47). Dla postsowieckiego obywatela charakterystyczne jest utożsamianie się z rolą ofiary, będące sygnałem dominacji dyskursu cierpienia, jednak z pominięciem odpowiedzialności za kształt historycznej rzeczywistości. Brak poczucia winy sprawia, że zło nie zostaje zdefiniowane, zrozumiane i nazwane, a to z kolei wpływa na osobowość degradująco, ponieważ zatraca się wrażliwość na drugiego człowieka.

Wariant człowieka opancerzonego rozpatrywany jest w pracy Skotnickiej również na przykładzie powieści Sienczina Rodzina Jołtyszewów, dotykającej problemu degradacji rodziny. W przypadku głównego bohatera tego utworu mamy do czynienia z typem homo postsovieticus, człowiekiem niemogącym porzucić stylu myślenia typowego dla epoki sowieckiej. Jak dowodzi krakowska badaczka, pisarz tworzy obrazy swoich postaci „na jakimś pęknięciu, nie- 
adekwatności, sprzeczności pomiędzy tym, co zewnętrzne i wewnętrzne, faktyczne i pozorne, udawane" (s. 79), sytuując człowieka w stanie między nudą a rozpaczą. Bohaterowie ukrywają prawdziwe uczucia, wykazują nadmierne zainteresowanie sprawami materialnymi, w swoich zachowaniach kierują się przede wszystkim instynktem bezpieczeństwa. Cechują ich brak świadomości bycia niepowtarzalną jednostką oraz tożsamościowa niespójność, świadcząca o ich martwocie duchowej. „Sienczin przedstawia bohaterów w stanie niemocy, a w gruncie rzeczy - depersonalizacji, zawieszenia pomiędzy nudą, płynącą z rutynowego stosunku do życia, a przypływami rozpaczy, pragnieniem śmierci i nieistnienia” (s. 89).

Problem relacji międzyludzkich w prozie Pietruszewskiej i Ulickiej jest przedmiotem analizy w drugim rozdziale monografii, poświęconym demilitaryzacji świadomości. W tekstach pierwszej z pisarek mamy do czynienia z człowiekiem skrzywdzonym, u drugiej - dominuje bohater stojący przed wyzwaniem redefinicji własnej tożsamości. W poddanym krytycznej refleksji utworze Taka dziewczynka, sumienie świata Pietruszewska zestawia portrety dwóch kobiet: narratorki Pietrowej oraz doświadczonej ciężko przez los Raisy (typ „małego człowieka”), której życie zdaje się nie przedstawiać żadnej wartości. Znajomość obu kobiet jest okazją do przyjrzenia się kategorii przyjaźni i - jak wynika z konstrukcji ideowej opowiadania - jej demitologizacji, wskazania, że współcześnie cnota ta uległa trywializacji, co jest sygnałem szerszego zjawiska czasów ponowoczesnych - atomizacji więzi międzyludzkich. Skotnicka, zwracając uwagę na stosowany przez Pietruszewską chwyt podwojenia i rozdwojenia, prowadzący do systemu lustrzanych odbić, jakie tworzą relacje bohaterek, dowodzi, że kontakty te noszą znamiona patologii, opartej na przemocy wobec człowieka słabego, skrzywdzonego i poniżonego. Obie kobiety realizują różne warianty bytu „odczłowieczonego" (w aspekcie cielesnym i moralnym), reprezentując bohaterów, których tożsamość została silnie zredukowana.

Kwestia stosunku do Inności, charakterystyczna dla twórczości Ulickiej, została w monografii rozpatrzona na przykładzie powieści Daniel Stein, tłumacz. Tytułowy bohater to Żyd i chrześcijanin, a więc kwintesencja figury Innego i Obcego. Mężczyzna odznacza 
się postawą przedkładającą ducha nad literę prawa - jako duchowny szuka oparcia w nauce Jezusa Chrystusa, a nie nadbudowanych nad nią obrzędach i przepisach kanonicznych. Ta dialogiczna w warstwie narracyjnej powieść koncentruje się na osobie bohatera współodczuwającego, zdolnego rozumieć przeciwne strony sporu, dążącego do pogodzenia różnych racji. „Uczuciowość” obecna w konstrukcji protagonisty, tak właściwa pisarstwu Ulickiej i sytuująca jej dorobek w nurcie neosentymentalizmu, jest, jak przekonująco dowodzi krakowska badaczka, świadectwem „etycznej, uniwersalnej skali ocen” (s. 139). Stein to typ człowieka prawego, któremu właściwe są takie zalety, jak „skromność, bezpośredniość, obojętność wobec wartości obowiązujących czy modnych w społeczeństwie" (s. 145). Postawa bohatera zaś to całkowite (na poziomie zarówno zachowania, jak i języka) nastawienie na porozumienie z drugim człowiekiem. Znalazło to wyraz choćby w profesji protagonisty, która sytuuje go pomiędzy wieloma językami, kulturami, postawami względem życia, czyniąc go pośrednikiem w komunikacji.

W centrum zainteresowania współczesnych pisarzy rosyjskich znajdują się również kwestie ontologiczne, dlatego też autorka monografii, dostrzegając te zagadnienia, trzeci rozdział swojej książki zatytułowała Jak działa świat?. Przedmiotem analizy jest tu twórczość Władimira Makanina i Michaiła Szyszkina. Obu prozaików łączy, jak czytamy, „mariaż racjonalizmu (myśl) i irracjonalizmu (mit, obraz, intuicja)" (s. 151), co determinuje poetykę ich utworów, której głównym elementem jest dialektyczny ruch.

Co się tyczy twórczości Makanina, to bardzo ciekawe są rozważania o metaforze rzeki i błyskawicy. Obrazy te w twórczości autora Asana odsyłają zarówno do żywiołów wody i ognia, jak i do egzystencji, stając się sygnałem wzajemnie dopełniających się przeciwieństw, charakterystycznych dla ludzkiego życia. Błyskawica, symbolizująca zderzenie przeciwieństw, pozwala ujawnić „ukryty porządek i sens w tym, co niemożliwe do wyrażenia w języku odwołującym się do znaczeń przedmiotowych czy zmysłowych” (s. 161). Druga z metafor - rzeka - może mieć funkcję destrukcyjną, gdy niszczy skutki działań człowieka, ale również odzwierciedla zmienność życia, specyfikę ludzkiego istnienia od narodzin do śmierci. 
Jeden z podrozdziałów tej części opracowania poświęcony jest w całości opowieści Właz, której cechą jest, zdaniem Skotnickiej, szczelinowość, będąca znakiem „ukrycia, niepokoju” (s. 174). Analiza kategorii przestrzeni prowadzi autorkę monografii do postawienia tezy, że zawarty w utworze obraz miasta wykazuje cechy labiryntu, pułapki, w której bohater odczuwa bezradność i zagubienie oraz doznaje przemocy. Taka konstrukcja utworu poświadcza zainteresowanie Makanina kondycją ludzką, której główną wartością wydaje się walka o przetrwanie. Dychotomiczne podziały wertykalne (ziemia i podziemie) odzwierciedlają dwie sfery życia człowieka: cielesną, materialną i duchową, niewidoczną, których momentem styku jest tytułowy właz. Interpretacja tego utworu poświadcza wcześniejsze sugestie autorki, że głównym problemem twórczości Makanina jest refleksja dotycząca jedności przeciwieństw. Sięganie przez pisarza do sfery nieświadomości człowieka włącza w obszar artystycznego namysłu kwestie przebudzenia oraz skonfrontowania się z lękiem przed śmiercią i nadania życiu głębszego sensu. Przy czym Makanin nie odrzuca cielesności na rzecz zajmowania się wyłącznie sferą duchową, ale próbuje przekonać, że miłość do drugiego człowieka, współodczuwanie i wolność to kategorie nadrzędne.

W odniesieniu do twórczości Szyszkina krakowska badaczka proponuje perspektywę jej odczytania przez pryzmat zawartej w tekstach prozaika harmonii. Dbałość o szczegół, będący cechą pisarstwa Szyszkina, to sygnał, jak twierdzi autorka monografii, wyższego ładu rzeczywistości. W analizowanych utworach dostrzegalne jest napięcie pomiędzy światem widzialnym a niewidzialnym, prowadzące do sensualności przeżyć. Skotnicka wskazuje dwie zasady, które rządzą narracją i światem przedstawionym Szyszkinowskich tekstów, a są nimi: enantiodromia i harmonia, czyli współistnienie przeciwieństw, prowadzące do osiągnięcia kosmicznego ładu. Szyszkin chętnie czerpie z klasycznej tradycji, sprowadzając postacie do wzorców archetypowych (Mężczyzna, Kobieta, Dziecko), a archetypom egzystencjalnym towarzyszą archetypy kulturowe. Jednym z ważniejszych motywów prozy autora Włosu Wenery staje się miłość, która „leży u podstaw sztuki, głoszącej pochwałę życia w drobnych przejawach" (s. 222). 
Bardzo ciekawie brzmią filologiczne, oparte na genezie i semantyce słów, ale także odnoszące się do filozoficznych źródeł, analizy dotyczące apollińskich obrazów łuku i liry, obecnych w twórczości omawianego artysty. Pisarz wykorzystuje grę słów, zestawia cytaty, by wyeksponować dodatkowe sensy metafory, wykazując jej palimpsestowy charakter. Być może w stylu Szyszkina, próbującego zgłębić tajemnicę świata, tkwi siła tej prozy, tak niejednoznacznej, otwartej na wielość interpretacji rzeczywistości, która „bardziej się skrywa niż ujawnia” (s. 231).

Szyszkina, jak odnotowuje badaczka, interesuje problem śmierci, która jednakże w koncepcji tego pisarza nie jest przeciwstawiona życiu, lecz miłości. Eksponowanie dwukierunkowości świata rozszerza perspektywę jego oglądu, do której Szyszkin zachęca czytelnika, proponując mu zwrócenie się ku żywiołom (przede wszystkim ognia i powietrza) i zmysłom. Zdaniem Skotnickiej, strategie obierane przez pisarza prowadzą do uznania oscylacji (przepływania postaci jedna w drugą) za podstawową cechę świata prozy autora Zdobycia twierdzy Izmait.

Szkice, zaprezentowane w omawianej monografii, interpretowane są w szerokim kontekście historycznoliterackim, wskazującym z jednej strony na ciągłość procesów estetycznych na przestrzeni epok, z drugiej zaś - na zmagania bohaterów z tożsamością, wywołane nowoczesnymi procesami społecznymi i potrzebą ciągłego definiowania siebie. Szkoda, że tak mało (zaledwie siedem) utworów zostało wybranych do omówienia. Autorka pozostawia czytelnika z wyraźnym niedosytem poznawczym, głodem analitycznym, szczeliną intelektualną, która - miejmy nadzieję - zostanie w przyszłości zapełniona nowymi rozważaniami krakowskiej badaczki. Siłą monografii, oprócz zawartości merytorycznej, jest język - elegancja dyskursu, umiejętność przekazu skomplikowanych procesów psychologicznych i literaturoznawczych w sposób klarowny, a jednocześnie nienużący sprawiają, że lektura opracowania to czytelnicza przyjemność. 